\title{
Gambaran elektrolit serum pada anak dengan diare akut
}

\author{
${ }^{1}$ Christin V. Wololi \\ ${ }^{2}$ Jeanette I. Ch. Manoppo \\ ${ }^{2}$ Novie H. Rampengan
}

\author{
${ }^{1}$ Kandidat Skripsi Fakultas Kedokteran Universitas Sam Ratulangi Manado \\ ${ }^{2}$ Bagian/SMF Ilmu Anak Fakultas Kedokteran Universitas Sam Ratulangi Manado \\ Email: christinwololi@yahoo.com
}

\begin{abstract}
Acute diarrhea is defined as the sudden onset of 3 or more loose stools per day and lasts no longer than 14 days; chronic or persistent diarrhea lasts more than 14 days. Loss of fluid in large quantitiy such as diarrhea results in imbalance of fluid and electrolyte. The first influenced electrolytes are sodium and chloride since both are extracellular electrolytes. This study aimed to obtain the profile of serum electrolytes in children with acute diarrhea. Thus was a descriptive retrospective study using medical record data of patients hospitalized in the Paediatrics Department of Prof. Dr. R. D. Kandou Manado Hospital in the period of January 2015 - December 2015. The results showed that the highest incidence was among males (30 cases; 65.21\%). Most cases were aged $1-<5$ years (23 cases; 50\%). Most serum sodium values were in the normal range (36 cases; 78.26\%). Most cases had diarrhea without dehydration and had normal serum sodium (20 cases; 43.47\%). Most cases had normal serum potassium levels (33 cases; 71.73\%). Most inpatients were without dehydration (17 cases; 36.95\%). Most cases had normal serum electrolyte levels (39 cases; 84.78\%). Most of the diarrhea without dehydration ( 21 cases; 45.65\%). Diarrhea was most often in those who were formula-fed (29 cases; 63.04\%).
\end{abstract}

Keywords: acute diarrhea, dehydration, electrolyte disturbance

\begin{abstract}
Abstrak. Diare akut didefinisikan sebagai onset mendadak 3 atau lebih mencret per hari dan berlangsung tidak lebih dari 14 hari sedangkan diare kronis atau persisten berlangsung lebih dari 14 hari. Bila terjadi kehilangan cairan dalam jumlah banyak secara terus menerus seperti pada diare maka keseimbangan cairan dan elektrolit dalam tubuh tidak dapat dipertahankan. Elektrolit yang pertama terpengaruh ialah natrium dan klorida karena keduanya merupakan elektrolit ekstrasel. Penelitian ini bertujuan untuk mendapatkan gambaran elektrolit serum pada anak dengan diare akut. Jenis penelitian retrospektif deskriptif menggunakan data rekam medik pasien rawat inap di Bagian Pediatri RSUP Prof. Dr. R.D. Kandou Manado periode Januari 2015 - Desember 2015. Hasil penelitian memperlihatkan bahwa insiden tertinggi pada laki-laki sebanyak 30 kasus (65,21\%). Usia terbanyak antara 1 tahun $-<5$ tahun yaitu 23 kasus (50\%). Nilai natrium serum paling banyak pada kisaran normal yaitu 36 kasus (78,26\%), paling banyak didapatkan pada penderita tanpa dehidrasi dengan natrium serum normal 20 kasus (43,47\%). Kadar kalium serum normal secara keseluruhan berjumlah 33 kasus (71,73\%), paling banyak pada penderita tanpa dehidrasi yaitu 17 kasus (36,95\%). Kadar serum paling banyak pada kisaran normal yaitu 39 kasus (84,78\%), dan paling banyak pada penderita tanpa dehidrasi yaitu 21 kasus (45,65\%). Diare paling banyak pada yang diberi susu formula sebanyak 29 kasus $(63,04 \%)$.
\end{abstract}

Kata kunci: diare akut, dehidrasi, gangguan elektrolit

Diare adalah kebalikan dari status dan elektrolit terhadap sekresi. Diare akut penyerapan normal total dari absorbsiair didefinisikan sebagai onset mendadak 3 
atau lebih mencret per hari dan berlangsung tidak lebih dari 14 hari sedangkan diare kronis berlangsung lebih dari 14 hari. Perbedaan ini memiliki implikasi tidak hanya untuk klasifikasi dan studi epidemiologi tetapi juga dari sudut pandang praktis, karena diare berkepanjangan sering memiliki etiologi yang berbeda, masalah penanganan dan prognosis yang berbeda. ${ }^{1,2}$

Diare akut masih merupakan penyebab utama morbiditas dan mortalitas anak di dunia terutama dinegara berkembang. Kasus diare diseluruh dunia mencapai 1,7 milliar kasus diare setiap tahun, dan membunuh sekitar 760 ribu anak usia dibawah 5 tahun. Jumlah ini mencapai 18 $\%$ dari seluruh kematian pada anak usia dibawah 5 tahun dan ini berarti bahwa lebih dari 5000 anak meninggal setiap hari akibat diare, 78 \% terjadi di bagian Afrika dan Asia Tenggara. ${ }^{3,4}$ Di Indonesia sendiri, dari daftar urutan penyebab kunjungan puskesmas/balai pengobatan, hampir selalu termasuk dalam kelompok 3 penyebab utama ke puskesmas. Angka kesakitannya adalah sekitar 200 - 400 kejadian diare diantara 1000 penduduk setiap tahunnya. Dengan demikian di Indonesia diperkirakan ditemukan penderita diare sekitar 60 juta kejadian setiap tahunnya, sebagian besar (70\%-80\%) dari penderita ini adalah anak dibawah umur 5 tahun ( \pm 40 juta kejadian). ${ }^{5}$ Hasil Riset Kesehatan Daerah (RISKESDAS) tahun 2013 dan berdasarkan profil kesehatan Indonesia dari Kementerian Kesehatan RI menunjukkan prevalensi nasional diare klinis pada anakanak adalah 7,0 \%. Insiden diare di Sulawesi Utara sebesar 6,6 \%. ${ }^{6,7}$

Penyebab diare dengan onset akut diantaranya infeksi seperti infeksi enterik (keracunan makanan) dan infeksi ekstraintestinal. Selain itu ada diare akut yang diinduksi oleh obat-obatan seperti laksatif, antasida yang mengandung magnesium, gejala sisa opiat dan obatobatan lain. Alergi makanan atau intoleransi adalah penyebab lain diare pada anak seperti alergi protein susu sapi, protein susu kedelai. Gangguan pada usus/proses absorbsi seperti malabsorbsi glukosa-laktosa, defisiensi sukraseisomaltase dapat menyebabkan diare. ${ }^{1}$

Patofisiologi gangguan elektrolit pada diare dan kecepatan hilangnya elektrolit tergantung pada penyebab diare. Pada diare osmotik tekanan osmotic usus yang kuat akan mendorong air dan elektrolit dengan cepat sehingga abrsobsi tidak terjadi, pada kasus ini defisiensi elektrolit cepat terjadi. Kecepatan hilangnya elektrolit lebih rendah pada diare sekretorik. Diare sekretorik yang disebabkan oleh kolera akut memperlihatkan konsentrasi $\mathrm{Na}^{+}, \mathrm{K}^{+}$, dan $\mathrm{Cl}^{-}$tidak jauh berbeda dengan konsentrasi plasma, namun bila berlangsung lama gangguan elektrolit akan menjadi lebih berat. Pada diare eksudatif dimana terjadi kerusakan barrier epitel dan banyak sel epitel intestinal yang hilang. pada jenis diare ini, terjadi peningkatan tekanan hidrostatik pada pembuluh darah dan limfatik sehingga absorbsi air dan elektrolit tidak terjadi, sehingga air, elektrolit, mucus, protein, bahkan kadang-kadang eritrosit dan leukosit akan terakumulasi dalam lumen usus. Gangguan elektrolit pada diare karena gangguan motilitas (meningkat atau menurun) menyebabkan pertumbuhan bacterial meningkat dengan cepat sehingga memicu terjadinya diare baik osmotic maupun sekretorik. ${ }^{10}$

Dehidrasi atau kekurangan cairan dalam tubuh menyebabkan penurunan volume ekstraselular yang menyebabkan berkurangnya perfusi jaringan memicu gangguan fungsi organ-organ tubuh., Secara normal, tubuh bisa mempertahankan diri dari ketidak seimbangan cairan dan elektolit. Namun, ada kalanya tubuh tidak bisa mengatasinya. Ketika tubuh mengalami kehilangan cairan dalam jumlah yang banyak secara terus menerus seperti pada diare maka tubuh sudah tidak bisa mempertahankan keseimbangan cairan dan elektrolit dalam tubuh. Elektrolit yang pertama terpengaruh ialah natrium dan klorida karena keduanya merupakan elektrolit ekstrasel dalam tubuh. ${ }^{2}$

\section{METODE PENELITIAN}

Jenis penelitian ini retrospektif 
deskriptif menggunakan data rekam medik untuk mengetahui gambaran elektrolit serum pasien rawat inap dengan diare di Bagian Peditari RSUP Prof. Dr. R.D. Kandou Manado

Populasi penelitian ini ialah seluruh penderita diare akut yang dirawat di bagian Rawat Inap Anak RSUP. Prof. Dr. R. D. Kandou Manado periode Januari-Desember 2015. Sampel yang digunakan merupakan seluruh populasi rekam medik yang memenuhi kriteria inklusi dan eksklusi yaitu sebanyak 46 sampel. Kriteria eksklusi penelitian ini ialah penyakit diare kronis, diare akut dengan penyakit penyerta yang dapat menyebabkan gangguan elektrolit dan status rekam medis yang tidak lengkap.

\section{HASIL PENELITIAN DAN BAHASAN}

Tabel 1 memperlihatkan bahwa kelompok jenis kelamin dengan frekuensi tertinggi ialah laki-laki dengan jumlah responden sebanyak 30 orang (65,21\%). Kasus terbanyak diare tanpa dehidrasi dan diare dengan dehidrasi ringan-sedang terjadi pada laki-laki masing-masing sebanyak 17 kasus (36,95\%) dan 13 kasus (28,26\%).

Tabel 2 menunjukkan penderita diare terbanyak pada usia 1 tahun $-<5$ tahun yaitu 23 kasus (50\%) dan usia 1 bulan- $<1$ tahun yaitu 20 kasus (43,47\%). Terdapat kasus diare dengan usia tertinggi, yaitu 5 tahun - $<10$ tahun dan $>10$ tahun, masing masing 2 kasus (4,33\%) dan 1 kasus (2,17\%).

Tabel 1. Distribusi responden berdasarkan jenis kelamin

\begin{tabular}{|c|c|c|c|c|c|c|c|c|}
\hline \multirow[t]{2}{*}{ Jenis kelamin } & \multicolumn{2}{|c|}{$\begin{array}{c}\text { Diare tanpa } \\
\text { dehidrasi }\end{array}$} & \multicolumn{2}{|c|}{$\begin{array}{c}\text { Diare dehidrasi } \\
\text { ringan-sedang }\end{array}$} & \multicolumn{2}{|c|}{$\begin{array}{c}\text { Diare dehidrasi } \\
\text { berat }\end{array}$} & \multicolumn{2}{|c|}{ Jumlah } \\
\hline & $\mathrm{n}$ & $\%$ & $\mathrm{n}$ & $\%$ & $\mathrm{n}$ & $\%$ & $\mathrm{n}$ & $\%$ \\
\hline Laki-laki & 17 & 36,95 & 13 & 28,26 & 0 & 0 & 30 & 65,21 \\
\hline Perempuan & 7 & 15,21 & 8 & 17,39 & 1 & 2,17 & 16 & 36,78 \\
\hline Jumlah & 24 & 52,17 & 21 & 45,65 & 1 & 2,17 & 46 & 100 \\
\hline
\end{tabular}

Tabel 2. Distribusi responden berdasarkan kelompok umur

\begin{tabular}{lcccccccc}
\hline \multirow{2}{*}{ Umur } & \multicolumn{2}{c}{$\begin{array}{c}\text { Diare tanpa } \\
\text { dehidrasi }\end{array}$} & \multicolumn{2}{c}{$\begin{array}{c}\text { Diare dehidrasi } \\
\text { ringan sedang }\end{array}$} & \multicolumn{2}{c}{$\begin{array}{c}\text { Diare dehidrasi } \\
\text { berat }\end{array}$} & \multicolumn{2}{c}{ Jumlah } \\
\cline { 2 - 10 } & $\mathrm{n}$ & $\%$ & $\mathrm{n}$ & $\%$ & $\mathrm{n}$ & $\%$ & $\mathrm{n}$ & $\%$ \\
\hline 1 bulan $-<1$ tahun & 11 & 23,91 & 9 & 19,56 & 1 & 2,17 & 20 & 45,65 \\
1 tahun $-<5$ tahun & 9 & 19,56 & 14 & 30,43 & 0 & 0 & 23 & 50 \\
5 tahun $-<10$ tahun & 1 & 2,17 & 1 & 2,17 & 0 & 0 & 2 & 4,33 \\
10 tahun $-<18$ tahun & 1 & 2,17 & 0 & 0 & 0 & 0 & 1 & 2,17 \\
Jumlah & 21 & 45,65 & 24 & 52,17 & 1 & 2,17 & 46 & 100 \\
\hline
\end{tabular}

Tabel 3 memperlihatkan nilai natrium serum rendah pada 6 kasus (13,04\%), natrium serum normal pada 36 kasus (78,26\%), dan natrium serum tinggi 4 kasus $(8,69 \%)$ dengan nilai natrium serum $<135$ $\mathrm{mmol} / \mathrm{l}$ dan $>150 \mathrm{mmol} / \mathrm{l}$. Pada diare tanpa dehidrasi yang memiliki nilai natrium serum rendah 3 kasus (6,52\%), natrium serum normal 20 kasus $(43,47 \%)$, natrium serum tinggi 1 kasus (2,17\%). Pada diare dengan dehidrasi ringan-sedang yang memiliki nilai natrium serum rendah 3 kasus (6,52\%), nilai natrium serum normal 16 kasus (34,78\%), nilai natrium serum tinggi 2 kasus (4,34\%) Pada diare dengan dehidrasi berat yang memiliki nilai natrium serum tinggi 1 kasus (2,17\%).

Tabel 4 memperlihatkan nilai kalium serum rendah pada penderita diare akut 10 kasus (21,73\%), kalium serum normal 33 kasus (71,73\%), kalium serum tinggi 3 kasus (6,52\%), dengan nilai kalium serum 
$<3,5 \mathrm{mmol} / \mathrm{l}$ dan $>5,8 \mathrm{mmol} / \mathrm{l}$. Pada diare tanpa dehidrasi yang memiliki nilai kalium serum rendah 5 kasus $(10,86 \%)$, kalium serum normal 17 kasus (36,95\%), dan kalium serum tinggi 2 kasus (3,34\%). Pada diare dengan dehidrasi ringan-sedang yang memiliki nilai kalium serum rendah 5 kasus $(10,86 \%)$, kalium serum normal 15 kasus (32,60\%), dan kalium serum tinggi 1 kasus (2,17\%). Pada diare dengan dehidrasi berat yang memiliki nilai kalium serum normal 1 kasus (2,17\%).

Tabel 5 memperlihatkan kadar klorida serum normal pada penderita diare akut 39 kasus $(84,78 \%)$ dan kadar klorida serum tinggi 7 kasus $(15,21 \%)$ dengan nilai klorida serum $<94 \mathrm{mmol} / \mathrm{l}$ dan $>112$ $\mathrm{mmol} / \mathrm{l}$. Pada diare tanpa dehidrasi yang memiliki nilai klorida serum normal 21 kasus (45,65\%) dan klorida serum tinggi 3 kasus (6,52\%). Pada diare dengan dehidrasi ringan-sedang yang memiliki nilai klorida serum normal 18 kasus $(10,86 \%)$ dan klorida serum tinggi 3 kasus (6,52\%). Pada diare dengan dehidrasi berat yang memiliki nilai klorida serum tinggi 1 kasus (2,17\%).

Tabel 6 memperlihatkan bahwa kelompok bayi yang diberi asi eksklusif 17 kasus (36,95\%), bayi yang diberi susu formula 29 kasus (63,04\%).

Kasus diare akut yang dirawat di bangsal anak RSUD Prof. Dr. R. D. Kandou Manado periode Januari-Desember 2015 sebanyak 70 kasus dan terdapat 46 kasus yang memenuhi kriteria penelitian. Sebagian kasus merupakan diare berdarah 14 kasus, dan diare akut dengan penyakit penyerta yang memengaruhi elektrolit 10 kasus. Pada penelitian ini ditemukan lebih banyak kasus diare akut tanpa dehidrasi yaitu 23 kasus, dehidrasi ringan sedang 22 kasus dan dehidrasi berat 1 kasus.

Penentuan derajat dehidrasi berdasarkan manifestasi klinis, juga anamnesis dari keluarga pasien. Diare dengan dehidrasi dapat menyebabkan kehilangan elektrolit serum, apalagi bila berlangsung secara terus menerus dan tidak diberi penanganan, terutama pada keluarga atau orang tua pasien yang baru pertama kali mengalami diare.

Patogenesis hiponatremia pada diare disebabkan oleh kombinasi hilangnya sodium dan air dan retensi air untuk mengkompensasi hilangnya volume. Akan tetapi, kebanyakan cairan yang hilang pada diare memiliki konsentrasi sodium yang rendah. Jadi pasien dengan kehilangan hanya cairan saja bisa mengalami hipernatremia, seperti beberapa pasien dalam penelitian ini.

Tabel 3. Distribusi responden berdasarkan hasil pemeriksaan natrium serum

\begin{tabular}{lcccccccc}
\hline \multirow{2}{*}{ Natrium } & \multicolumn{2}{c}{$\begin{array}{c}\text { Diare tanpa } \\
\text { dehidrasi }\end{array}$} & $\begin{array}{c}\text { Diare dehidrasi ringan } \\
\text { sedang }\end{array}$ & \multicolumn{2}{c}{$\begin{array}{c}\text { Diare dehidrasi } \\
\text { berat }\end{array}$} & \multicolumn{2}{c}{ Jumlah } \\
\cline { 2 - 10 } & $\mathrm{n}$ & $\%$ & $\mathrm{n}$ & $\%$ & $\mathrm{n}$ & $\%$ & $\mathrm{n}$ & $\%$ \\
\hline Rendah & 3 & 6,52 & 3 & 6,52 & 0 & 0 & 6 & 13,04 \\
Normal & 20 & 43,47 & 16 & 34,78 & 0 & 0 & 36 & 78,26 \\
Tinggi & 1 & 2,17 & 2 & 4,34 & 1 & 2,17 & 4 & 8,69 \\
Jumlah & 24 & 52,17 & 21 & 45,65 & 1 & 2,17 & 46 & 100 \\
\hline
\end{tabular}

Tabel 4. Distribusi responden berdasarkan hasil pemeriksaan kalium serum

\begin{tabular}{|c|c|c|c|c|c|c|c|c|}
\hline \multirow[t]{2}{*}{ Kalium } & \multicolumn{2}{|c|}{$\begin{array}{l}\text { Diare tanpa } \\
\text { dehidrasi }\end{array}$} & \multicolumn{2}{|c|}{$\begin{array}{c}\text { Diare dehidrasi ringan } \\
\text { sedang }\end{array}$} & \multicolumn{3}{|c|}{ Diare dehidrasi berat jumlah } & \multirow[b]{2}{*}{$\%$} \\
\hline & $\mathrm{n}$ & $\%$ & $\mathrm{n}$ & $\%$ & $\mathrm{n}$ & $\%$ & $\mathrm{n}$ & \\
\hline Rendah & 5 & 10,86 & 5 & 10,86 & 0 & 0 & 10 & 21,73 \\
\hline Normal & 17 & 36,95 & 15 & 32,60 & 1 & 2,17 & 33 & 71,73 \\
\hline Tinggi & 2 & 3,34 & 1 & 2,17 & 0 & 0 & 3 & 6,52 \\
\hline Jumlah & 24 & 52,17 & 21 & 45,65 & 1 & 2,17 & 46 & 100 \\
\hline
\end{tabular}


Tabel 5. Distribusi responden berdasarkan hasil pemeriksaan klorida serum

\begin{tabular}{lcccccccc}
\hline \multirow{2}{*}{ Klorida } & \multicolumn{2}{c}{$\begin{array}{c}\text { Diare tanpa } \\
\text { dehidrasi }\end{array}$} & \multicolumn{2}{c}{$\begin{array}{c}\text { Diare dehidrasi } \\
\text { ringan sedang }\end{array}$} & \multicolumn{2}{c}{$\begin{array}{c}\text { Diare dehidrasi } \\
\text { berat }\end{array}$} & \multicolumn{2}{c}{ Jumlah } \\
\cline { 2 - 9 } & $\mathrm{n}$ & $\%$ & $\mathrm{n}$ & $\%$ & $\mathrm{n}$ & $\%$ & $\mathrm{n}$ & $\%$ \\
\hline Normal & 21 & 45,65 & 18 & 10,86 & 0 & 0 & 39 & 84,78 \\
Tinggi & 3 & 6,52 & 3 & 6,52 & 1 & 2,17 & 7 & 15,21 \\
Jumlah & 24 & 52,17 & 21 & 45,65 & 1 & 2,17 & 46 & 100 \\
\hline
\end{tabular}

Tabel 6. Distribusi responden berdasarkan pemberian ASI

\begin{tabular}{lcccccccc}
\hline \multirow{2}{*}{ Asi } & \multicolumn{2}{c}{$\begin{array}{c}\text { Diare tanpa } \\
\text { dehidrasi }\end{array}$} & \multicolumn{2}{c}{$\begin{array}{c}\text { Diare dehidrasi } \\
\text { ringan sedang }\end{array}$} & \multicolumn{2}{c}{$\begin{array}{c}\text { Diare } \\
\text { dehidrasi berat }\end{array}$} & \multicolumn{2}{c}{ Jumlah } \\
\cline { 2 - 11 } & $\mathrm{n}$ & $\%$ & $\mathrm{n}$ & $\%$ & $\mathrm{n}$ & $\%$ & $\mathrm{n}$ & $\%$ \\
\hline Asi eksklusif & 7 & 15,21 & 9 & 19,56 & 1 & 2,17 & 17 & 36,95 \\
Susu formula & 17 & 36,95 & 12 & 26,08 & 0 & 0 & 29 & 63,04 \\
Jumlah & 24 & 52,17 & 21 & 45,65 & 1 & 2,17 & 46 & 100 \\
\hline
\end{tabular}

Hal yang sama bisa terjadi pada elektrolit lain seperti kalium dan klorida, sehingga pada diare akut sedikit gangguan elektrolit yang ditemukan dan kebanyakan hasil laboratorium elektrolit normal, seperti pada penelitian ini. Penjelasan lain terjadinya hipernatre-mia oleh karena ketidak cukupan intake air bebas sodium atau peningkatan intake sodium karena larutan rehidrasi oral yang tidak tepat. ${ }^{11}$ Pengukuran elektrolit serum diperlukan pada beberapa anak dengan durasi diare yang lebih lama dengan dehidrasi sedang atau berat, terutama dengan riwayat klinis yang tidak khas. Dehidrasi hipernatremik lebih sering terjadi pada anak-anak dengan gizi baik dan mereka yang terinfeksi rotavirus. $^{4}$

Pemberian ASI eksklusif memengaruhi morbiditas diare, pemeberian asi sangat berpengaruh pada kejadian diare, dimana pasien yang tidak diberi ASI eksklusif paling rentan menderita diare. Proteksi yang diberikan oleh asi terlihat melalui dua cara yaitu, menurunkan insiden diare dan menurunkan durasi diare. Pemeberian ASI terlihat lebih memengaruhi penurunan prevalensi diare dibandingkan dengan insiden. Diduga bahwa mekanisme yang menonjol dari pemeberian asi adalah penurunan mortalitas diare melalui pengurangan episode diare. ${ }^{12}$

\section{SIMPULAN}

1. Diare terbanyak terdapat pada anak laki-laki dibanding perempuan

2. Jumlah diare terbanyak ditemukan pada kelompok usia 1- $<5$ tahun tahun, sebanyak 23 (50\%)

3. Komplikasi diare akut dengan dehidrasi terbanyak ialah hipokalemia

4. Jumlah penderita diare terbanyak pada anak yang hanya diberi ASI saja

\section{SARAN}

1. Morbitas dan mortalitas diare akut pada bayi usia dibawah 5 tahun sangat tinggi terutama karena dehidrasi dan gangguan elektrolit, penanganan dini sangat dibutuhkan.

2. Penyuluhan pada orang tua perlu dilakukan agar dapat mengurangi morbiditas dan mortalitas akibat diare.

3. Penelitian ini dapat menjadi masukan bagi penelitian selanjutnya

\section{DAFTAR PUSTAKA}

1. Guandalini S, Frye RE, Tamer MA, Windle ML, Cuffari C. Medscape Refference. [Online].; 2015 [cited 2015 December 27. Available from: http://emedicine.medscape.com/article/ 
928598-overview

2. Juffrie M, Soenarto SSY, Oswan H, Arief S, Rosalina I, Mulyani NS. Buku ajar Gastroentero-Hepatologi. Jakarta: Badan Penerbit IDAI, 2011.

3. WHO. Diarrhoeal disease. WHO Media Centre; 2013.

4. Farthing M, Salam M, Lindberg G, Dite $P$, Khalif I, Zalasar-Lindo E, et al. Acute diarrhea in adults and children: a global perspective. World Gastroenterology Organization. Global Guidelines and Cascades; 2012 February.

5. Widayana IW, Gandi. Konsentrasi pelaksanaan program serta morbiditas dan mortalitas diare di era otonomi dan krisis. Kumpulan makalah Kongres nasional II BKGAI Bandung. 2003; p. 45-54.

6. RISKESDAS. Riset kesehatan dasar. 2013: p. 72-4.
7. Kementerian Kesehatan RI. Profil kesehatan Indonesia tahun 2014. 2015: p. 147

8. Dwipoerwantoro PG, Hegar B, Pustika AW, Witjaksono. Pola tata laksana diare akut di beberapa rumah sakit swasta di Jakarta; apakah sesuai dengan protokol WHO? Sari Pediatri. 2008;6(4):182-7.

9. Departemen Kesehatan RI. Profil kesehatan Indonesia 2008 Jakarta ; 2009.

10. Rudolph JA, Rufo PA. Diarrhea. In Benson JB, Haith MM. Disease and disorder in infancy and early childhood. San Diego: Elsevier, 2004; p. 130-7.

11. Shah G, Das B, Kumar S, Singh M, Bhandri G. Electrolyte distrubances in diarrhea. Ped On Call. 2006; 3(11):1-8

12. Lamberti M, Walker CL, Black NV. Breastfeeding and the risk for diarrhea morbidity and mortality. BMC Public Health. 2011;11(3):3-12. 